\title{
PENGARUH CONTEXTUAL TEACHING AND LEARNING (CTL) TERHADAP KEMAMPUAN SAINS PERMULAAN ANAK TAMAN KANAK-KANAK
}

\author{
I Ketut Gading ${ }^{1}$, Putu Aditya Antara ${ }^{2}$, Arizka Salsabila Hidayat ${ }^{3}$ \\ 1,2,3Universitas Pendidikan Ganesha \\ Singaraja, Indonesia \\ e-mail: iketut.gading@undiksha.ac.id ${ }^{1}$, putuaditya.antara@undiksha.ac.id², \\ arizka.salsabila.hd@undiksha.ac.id ${ }^{3}$
}

\begin{abstract}
Abstrak
Penelitian ini bertujuan untuk mengetahui pengaruh model pembelajaran CTL (Contextual Teaching and Learning) terhadap kemampuan sains permulaan anak kelompok B Taman Kanak-kanak Gugus V Kecamatan Klungkung. Penelitian iniadalah penelitian eksperimen semu (quasi eksperiment). Desain penelitiannya adalah Non Equivalen Pretest-Posttest Control Group Desain. Populasi dalam penelitian ini adalah sebanyak 175 anak Taman Kanak-kanak yang berada di gugus $V$ Kecamatan Klungkung. Sampel penelitian dipilih secara acak 2 kelas dari 8 kelas anggota populasi, sehingga diperoleh anak kelompok B TK Nurul Huda sebagai kelompok eksperimen dan anak kelompok B TK Kumara Dewa sebagai kelompok kontrol. Untuk mengumpulkan data tentang kemampuan sains permulaan digunakan pedoman observasi yang teruji validitas dan reliabilitasnya. Untuk menguji hipotesis data diuji dengan uji-t. hasil penelitian menunjukkan terdapat pengaruh model pembelajaran Contextual Teaching and Learning terhadap kemampuan sains permulaan anak Taman Kanak-kanak $(\mathrm{t}=11,278>$ Sig. $(2$-tailed $)$ 0,000).
\end{abstract}

Kata-kata kunci : CTL, Sains Permulaan, AUD

\begin{abstract}
This study aims to determine the effect of the CTL (Contextual Teaching and Learning) learning model on the scientific ability of children in Group B of Kondergarten Cluster V in Klungkung Subdistrict. This research is quasi experimental. The research design is Non Equivalent Pretest-Posttest Control Group Desain. The population in this study were 175 kindergartens in the V cluster of Klungkung Subdistrict. The study sample wa randomly selected 2 classes from 8 classes of population members, so that the children of group B TK Nurul Huda were obtained as the experimental group and the children in the group B TK Kumara Dewa as a control group. To collect data on early science skills, observation guidelines were used that tested their validity and reliability.To test the hypothesis the data was tested by t-test. The results of the study showed that there was an influence of the Contextual Teaching and Learning learning model on the science abilities of early childhood kindergarten ( $1=11,278>$ Sig.(2-tailed) 0,000$)$.
\end{abstract}

Keywords: CTL, Beginning Science, AUD

\section{Pendahuluan}

Setiap manusia membutuhkan pendidikan dalam kehidupannya. Pendidikan merupakan usaha agar manusia dapat mengembangkan potensi dirinya melalui proses pembelajaran. Pendidikan memiliki kaitan yang erat dengan sekolah, karena sekolah merupakan tempat memperoleh pendidikan secara formal, perlu disadari bahwa proses pembelajaran merupakan bagian yang sangat penting dari pendidikan. Pendidikan merupakan penggerak bagi pembangunan bangsa dan negara, salah satu kebijakan pemerintah yang dapat kita lihat adalah dibentuknya pendidikan anak usia dini. 
Pendidikan anak usia dini adalah pendidikan yang cukup penting dan bahkan menjadi landasan kuat untuk mewujudkan generasi yang lebih cerdas, berahlak, bermutu serta terampil. Sujiono (2009:2) menjelaskan bahwa "pendidikan pada masa usia dini merupakan wahana pendidikan yang sangat fundamental dalam memberikan kerangka dasar terbentuk dan berkembangnya dasar-dasar pengetahuan, sikap, dan keterampilan pada anak". Pendidikan anak usia dini adalah suatu proses pembinaan tumbuh kembang anak sejak lahir sampai usia 6 tahun, yang dilakukan secara menyeluruh, mencakup semua aspek perkembangan dengan memberikan stimulasi terhadap perkembangan jasmani dan rohani agar anak dapat tumbuh dan berkembang secara optimal. Hal ini menunjukkan bahwa seluruh potensi dan kecerdasan serta dasar-dasar perilaku seseorang telah mulai terbentuk pada usia ini.

Undang-undang Nomor 20 Tahun 2003 Pasal 28 tentang Sistem Pendidikan Nasional menyatakan bahwa pendidikan anak usia dini diselenggarakan sebelum jenjang pendidikan dasar, melalui jalur pendidikan formal, nonformal, dan informal. Pendidikan anak usia dini jalur formal meliputi Taman Kanak-kanak (TK), Raudhatul Atfal (RA), atau bentuk lain yang sederajat. Pendidikan anak usia dini jalur nonformal berbentuk Kelompok Bermain (KB), Taman Penitipan Anak (TPA), atau bentuk lain yang sederajat. Pendidikan anak usia dini jalur pendidikan informal berbentuk pendidikan keluarga atau pendidikan yang diselenggarakan oleh lingkungan.

Taman Kanak-kanak merupakan salah satu bentuk pendidikan jalur formal yang menyediakan program pendidikan bagi anak usia empat sampai enam tahun sebelum memasuki pendidikan sekolah dasar, karena Taman Kanak-kanak merupakan awal pendidikan sekolah oleh karena itu Taman Kanak-kanak perlu menciptakan situasi pendidikan yang dapat memberikan rasa aman, nyaman, dan menyenangkan. Pendidikan Taman Kanak-kanak bertujuan untuk membantu perkembangan sikap, keterampilan dan daya cipta yang diperlukan anak didik dalam menyesuaikan diri dengan lingkungannya. Dengan demikian pendidikan di TK pada umumnya untuk memfasilitasi pertumbuhan dan perkembangan anak secara optimal dan menyeluruh sesuai dengan norma-norma kehidupannya. Melalui pendidikan di TK anak diharapkan dapat mengembangkan aspek-aspek perkembangan yang dimilikinya.

Aspek perkembangan tersebut meliputi aspek sosial-emosional, bahasa, fisik motorik dan kognitif. Lima aspek perkembangan merupakan hal yang sangat penting dalam pencapaian perkembangan anak. Sekalipun aspek-aspek tersebut dibahas secara terpisahpisah namun sebenarnya saling berhubungan dan saling mempengaruhi satu sama lain. Dari semua aspek tersebut sama-sama bernilai dan sangat penting. Salah satu aspek penting yang perlu dikembangkan adalah aspek kognitif.

Menurut Suyadi (2010:8) "Perkembangan otak pada usia dini (0 - 6 tahun) mengalami percepatan hingga $80 \%$ dari keseluruhan otak orang dewasa (golden age)". Kemampuan kognitif merupakan suatu yang fundamental sangat sangat penting untuk distimulasi dengan optimal, sehingga dengan dikembangkannya kemampuan kognitif, anak akan mampu mengeksplorasikan keadaan sekitarnya melalui pancaindera dan dengan pengetahuan yang telah diterimanya akan membantu anak untuk melangsungkan hidupnya dan menjadi manusia yang utuh dimasa mendatang.

Mengutip pendapat dari (Susanto, 2011:48) mengatakan bahwa "Pengembangan kognitif adalah suatu proses berpikir, yaitu kemampuan individu untuk menghubungkan, menilai, dan mempertimbangkan suatu kejadian atau peristiwa". Kemampuan kognitif yang telah dimiliki dapat membantu anak untuk megenal, membedakan, membandingkan serta merasakan dengan baik apa yang telah dilihatnya, apa yang ada di sekitarnya dan apa yang ada di lingkungannya. "Adapun tujuan pengembangan kognitif diarahkan pada pengembangan kemampuan auditory, visual, taktik, kinestetik, aritmatika, geometri, dan sains permulaan" Susanto (2011:61).

Secara umum sains merupakan proses pengamatan, berfikir dan merefleksikan aksi dan kejadian atau peristiwa. Sains berhubungan dengan cara mencari tahu tentang alam secara sistematis, sains bukan hanya berupa fakta-fakta, konsep-konsep atau prinsip-prinsip saja, tetapi juga merupakan suatu proses penemuan. Pembelajaran sains penting diterapkan disetiap jenjang pendidikan untuk memberikan suatu pengenalan konsep. "Pembelajaran sains 
berarti suatu bidang ilmu yang mempelajari setiap fenomena alam yang terjadi di lingkungan sekitar dalam kehidupan sehari-hari" Susanto, (2016:169).

Nugraha (2005: 74) menjelaskan "Tingkatan pembelajaran sains untuk anak usia dini berada pada tahap permulaan, yaitu anak mempelajari sains dengan cara pengenalan dan perolehan sains yang benar". Lebih lanjut Salim dalam (Klarissa, 2018:10) menjelaskan "Sains permulaan adalah kemampuan yang berhubungan dengan berbagai percobaan atau dengan metode tertentu guna dalam pendekatan secara logis dan tetap mempertimbangkan tahapan berpikir anak".

Menurut Lind (dalam Sari, 2018:2) menyatakan "Sains permulaan adalah proses menemukan dan sebuah sistem untuk mengorganisasi dan melaporkan penemuan". Ketika anak usia dini dalam proses mengamati, memikirkan, dan merefleksikan tindakan dan even, maka mereka sedang belajar sains. ketika mereka mengorganisasi informasi faktual ke dalam konsep yang lebih bermakna, pemecahan, dan bertindak berdasarkan keingintahuan mereka, maka mereka sedang belajar sains.

Menurut Peraturan Menteri Pendidikan dan Kebudayaan RI Nomor 147 tahun 2014 kegiatan sains yang diajarkan pada anak usia dini adalah mengklasifikasikan berdasarkan fungsi, menunjukkan aktivitas bersifat eksploratif dan menyelidiki, menyusun perencanaan kegiatan yang akan dilakukan, mengenal sebab akibat tentang lingkungan, menunjukkan inisiatif dalam memililih tema, dan memecahkan permasalahan sederhana. Peraturan Menteri Pendidikan dan Kebudayaan RI Nomor 137 tahun 2014 menjelaskan bahwa "Kemampuan sains permulaan untuk anak usia 4-5 tahun yaitu anak dapat mengenal konsep sederhana dalam kehidupan sehari-hari, seperti gerimis, hujan, gelap, terang, temaram, dan sebagainya".

Berdasarkan pendapat di atas dapat disimpulkan bahwa kemampuan sains permulaan adalah kemampuan yang berhubungan dengan proses menemukan dengan melakukan berbagai percobaan-percobaan dimana anak mampu mengklasifikasi benda, menunjukan aktifitas yang bersifat eksploratif dan menyelidik, mengenal sebab akibat tentang lingkungan, serta memecahkan masalah sederhana dalam kehidupan sehari-hari secara kreatif, yang melibatkan anak untuk aktif menggunakan seluruh panca inderanya. Pengenalan dan pemerolehan sains harus dilakukan dengan cara yang benar yaitu mempertimbangkan tahapan berfikir, memahami karakteristik anak dan melihat sains dari sudut pandang anak agar tidak terjadi kekeliruan-kekeliruan dalam pembelajaran sains untuk anak.

Menurut Nugraha (2005:125) tahapan proses sains pada anak usia dini yang harus dikembangkan yaitu: tahapan proses sains pada anak usia dini yaitu (1) Mengamati, yaitu anak melibatkan kombinasi dari beberapa atau seluruh indera. Didalamnya terdapat kegiatan melihat, mendengar, meraba, mencicipi, mencium, merasakan. Dengan kegiatan ini anak terlibat langsung dengan lingkungan sekitar dan benda-benda yang ada disekelilingnya. (2) Mengklasifikasi atau menggelompokkan, merupakan suatu sistematika untuk mengatur obyekobyek ke dalam sederetan kelompok tertentu. Anak dapat belajar mencari persamaan dan perbedaan onjek-objek. (3) Menafsirkan atau meramalkan, yaitu suatu keterampilan membuat perkiraan tentang sesuatu yang belum terjadi. (4) Mengkomunikasikan, yaitu kemampuan anak dalam melaporkan hasil kegiatan sainsnya ke dalam bentuk tulisan, gambar, lisan, dan sebagainya serta penggunaan alat dan pengukuran, yaitu melatih anak untuk menggunakan alat ukur dengan teliti dan cermat.

Pengenalan sains penting untuk diterapkan sejak usia dini, karena dengan memberikan pengenalan sains pada anak dapat merangsang anak untuk berfikir kritis terhadap lingkungannya. Pengenalan sains juga berfungsi menstimulasi rasa ingin tahu, minat dan pemecahan masalah, sehingga memunculkan pemikiran dari perbuatan seperti mengobservasi, berfikir, dan mengaitkan antar konsep dan peristiwa. IImu sains tidak hanya membahas tentang kehidupan tetapi juga membahas tentang kejadian-kejadian yang ada di alam. IImu sains sangat kompleks sehingga membuat guru harus kreatif dalam menyajikan pembelajaran sains bagi anak usia dini. Pengenalan sains pada anak usia dini tentunya disesuaikan dengan karakteristik anak, disesuaikan dengan tema pembelajaran anak dan disesuaikan dengan tingkat perkembangan anak walaupun pembelajaran sains pada anak usia 
dini hanya sebatas pengenalan saja akan tetapi pembelajaran sains membantu anak untuk mengembangkan kemampuan berfikirnya.

Kesadaran akan pentingnya pembekalan sains pada anak akan semakin tinggi apabila menyadari bahwa manusia hidup di dunia yang dinamis, berkembang dan berubah secara terus menerus bahkan makin menuju masa depan, semakin komplek ruang lingkupnya, dan tentunya akan semakin memerlukan sains.

Berdasarkan penjajakan awal, kemampuan sains permulaan anak kelompok B di Taman Kanak-kanak Gugus V Kecamatan Klungkung, ditemukan berbagai permasalahan yang dapat teridentifikasi sebagai penyebab rendahnya kemampuan sains permulaan anak yaitu beberapa sekolah masih kurang dalam pemberian stimulasi terhadap kemampuan sains permulaan anak karena pembelajaran yang diterapkan disekolah monoton sehingga anak bersifat pasif dan tidak aktif dalam pembelajaran sains. Pembelajaran sains yang dilakukan guru disekolah lebih banyak menggunakan lembar kerja (LKS) daripada menggunakan alat praktik karena kurangnya ketersediaan alat praktik dan media disekolah. Pembelajaran sains di sekolah masih cenderung bersifat "teacher centered" guru cenderung berperan dominan dalam pembelajaran. Guru mengarahkan anak untuk belajar sesuai dengan apa yang diinginkan dan lebih menyukai hasil karya anak sesuai dengan apa yang diperintahkan, anak hanya mendengarkan dan mengikuti apa yang guru arahkan. Interaksi yang terjadi pada saat pembelajaran sains dikelas hanya satu arah yaitu pengetahuan hanya disampaikan oleh guru seperti contoh pada saat tema alam semesta guru hanya menjelaskan apa saja yang ada dialam semesta dan anak duduk pasif mendengarkan.

Berdasarkan hasil observasi, permasalahan yang ditemui pada anak kelompok B TK Gugus V Kecamatan Klungkung, maka alternatif pemecahan dari permasalahan tersebut yaitu dengan menerapkan model pembelajaran yang inovatif. Elizza (2013:3) "Model pembelajaran merupakan suatu rencana atau pola yang perlu disiapkan dalam menyusun kurikulum, merancang materi ajar, melaksanakan, membimbing dan mengevaluasi proses atau hasil pembelajaran". Selanjutnya Antara (2017:726) menjelaskan "Semua komponen pengajaran yang meliputi tujuan, bahan pelajaran, kegiatan belajar-mengajar, metode, alat dan sumber, serta evaluasi diperankan secara optimal guna mencapai tujuan pengajaran yang telah ditetapkan sebelum pengajaran dilaksanakan". Untuk itu model pembelajaran memiliki peranan yang sangat penting terhadap suatu proses pembelajaran.

Model pembelajan contextual teaching and learning (CTL) merupakan suatu pendekatan yang relevan dilakukan karena model pembelajaran contextual teaching and learning (CTL) adalah suatu konsep mengajar dan belajar yang membantu guru mengubungkan isi pelajaran dengan dunia nyata. Suastra (2013:113) menjelaskan "Model pembelajaran kontekstual merupakan suatu konsepsi pembelajaran yang membantu guru mengaitkan materi (content) yang diajarkan dengan situasi dunia nyata (context) dan mendorong siswa membuat hubungan antara pengetahuan yang dimilikinya dengan penerapannya dalam kehidupan mereka sehari-hari sebagai anggota keluarga, warga Negara, dan tenaga kerja". Proses pembelajaran berlangsung secara alamiah dalam bentuk kegiatan anak bekerja dan mengalami, bukan transfer pengetahuan dari guru ke anak.

Model pembelajaran contextual teacing and learning (CTL) memiliki kelebihan didalam penerapannya. Menurut Anisah (2009:1) bahwa terdapat 2 kelebihan model pembelajaran kontekstual yaitu : (1) pembelajaran menjadi lebih bermakna dan real. Artinya siswa dituntut untuk dapat menangkap hubungan antara pengalaman belajar di sekolah dengan kehidupan nyata. Hal ini sangat penting sebab dengan dapat mengorelasikan materi yang ditemukan dengan kehidupan nyata, (2) pembelajaran lebih produktif dan mampu menumbuhkan penguatan konsep kepada siswa karena metode pembelajaran CTL menganut aliran konstruktivisme, dimana seorang siswa dituntut untuk menemukan pengetahuannya sendiri. melalui landasan filosofis konstruktivisme siswa diharapkan belajar melalui "mengalami" bukan "menghafal". Dari uraian di atas dapat disimpulkan bahwa kelebihan model pembelajaran CTL adalah siswa lebih aktif dalam kegiatan pembelajaran dan pengetahuan siswa berkembang sesuai dengan pengalaman yang dialaminya. 
Dari pengertian yang telah dipaparkan dapat disimpulkan bahwa model pembelajaran kontekstual (CTL) adalah konsep belajar yang menghubungkan antara materi belajar dengan situasi dunia nyata yang dapat mendorong anak untuk menghubungkan antara pengetahuan yang dimilikinya dengan penerapannya dalam kehidupan sehari-hari. Hal ini tidak didasari oleh pemberian pembelajaran secara teori, namun bagaimana pembelajaran yang diberikan dapat berkaitan dengan kehidupan nyata anak dan terkait dengan masalah-masalah nyata yang dialami oleh anak.

Trianto (2009: 107) pembelajaran CTL melibatkan tujuh komponen utama, yaitu (1) konstruktivisme (constructivism), (2) bertanya (questioning), (3) inkuiri (inquiry), (4) masyarakat belajar (learning community), (5) permodelan (modeling), (6) refleksi (reflection), dan (7) penilaian autentik (authentic assessment). Ketujuh komponen ini harus diperhatikan guru saat menerapkan model pembelajaran CTL di kelas.

Pola pembelajaran Contextual Teaching And Learning dijelaskan Rusman (2012:34) pengembangan setiap komponen CTL tersebut dapat dilakukan sebagai berikut: (1) Mengembangkan pemikiran siswa untuk melakukan kegiatan belajar lebih bermakna apakah dengan cara bekerja sendiri, menemukan sendiri, dan mengonstruksi sendiri pengetahuan dan keterampilan baru harus dimilikinya. (2) Melaksanakan sejauh mungkin inquiry untuk semua topic yang dibicarakan. (3) Mengembangkan sifat ingin tahu siswa melalui memunculkan pertanyaan-pertanyaan. (4) Menciptakan masyarakat belajar, seperti melalui kegiatan kelompok, berdiskusi, tanya jawab, dan lain sebagainya. (5) Menghadirkan model sebagai contoh pembelajaran, bisa melalui ilustrasi, model, bahkan media yang sebenarnya. (6) Membiasakan anak untuk melakukan refleksi dari setiap kegiatan pembelajaran yang telah dilakukan. (7) Melakukan penilaian secara objektif, yaitu menilai kemampuan yang sebenarnya pada setiap siswa.

Berdasarkan latar belakang dalam penelitian ini adalah perlu adanya upaya yang dilakukan agar kemampuan sains permulaan pada anak dapat berkembang dengan baik.berkaitan dengan hal tersebut maka perlu diajukan penelitian yang berjudul pengaruh model pembelajaran contextual teaching and learning (CTL) terhadap kemampuan sains permulaan anak Taman Kanak-kanak.

\section{Metode}

Penelitian ini dilaksanakan di kelompok B Taman Kanak-kanak gugus V Kecamatan Klungkung, kelompok eksperimen diterapkan pada kelompok B di TK Nurul Huda Klungkung, sedangkan kelompok kontrol diterapkan pada TK Kumara Dewa Kamasan Klungkung. Penelitian ini dilaksanakan pada bulan mei sampai juni. Penelitian ini adalah penelitian eksperimen semu (quasi eksperiment) menggunakan desain Non Equivalen Pretest-Posttest Control Group Design

Populasi dari penelitian ini adalah sebanyak 175 anak yang berada di gugus $\mathrm{V}$ Kecamatan Klungkung. Sedangkan sampel berjumblah 60 anak. Tahapan-tahapan penelitian ini terdiri atas tahap persiapan, tahap pelaksanaan, dan tahap akhir. Pada tahap pelaksanaan kegiatan yang dilakukan adalah mengadakan observasi awal, pengambilan sampel penelitian, penyusunan rpph, membuat rancangan penelitian/instrumen, mengkonsultasikan instrumen bersama guru kelas. Tahap pelaksanaan yaitu memberikan perlakuan pada kelompok eksperimen menerapkan model pembelajaran contextual teaching and learning (CTL) dan untuk kelompok dibelajarkan seperti biasa. Perlakuan diberikan sebanyak 11 kali di kelas eksperimen. Dan pada tahap akhir memberikan post-test pada kelompok control dan kelompok eksperimen, menganalisis data hasil penelitian, melakukan uji hipotesis, dan menyusun laporan.

Pengambilan sampel penelitian dilakukan dengan mengundi kelompok-kelompok yang ada dalam populasi. Selanjutnya, dua kelas yang terpilih diberikan pre-test untuk diuji kesetaraannya menggunakan uji-t, uji persyarat yang meliputi uji normalitas dan homogenitas varians dilakukan terlebih dahulu sebelum dilakukan uji-t. Setelah kedua kelas dinyatakan setara, kedua kelas kemudian diundi kembali untuk menentukan kelompok eksperimen dan 
kelompok kontrol. Adapun beberapa faktor yang mempengaruhi hasil penelitian ini adalah validitas internal dan validitas eksternal. Metode pengumpulan data yang digunakan yaitu metode non tes. Metode non tes yang akan digunakan adalah observasi. Agung (2014:94) menyatakan bahwa "observasi adalah suatu cara untuk mengadakan penilaian dengan jalan mengadakan pengamatan secara langsung dan sistematis. Keunggulan metode observasi adalah hasilnya lebih akurat dan sulit dibantah". Menurut sugiyono (2017:172), metode pengumpulan data berupa observasi digunakan bila objek penelitian bersifat perilaku manusia, proses kerja, gejala alam, dan responden kecil. Metode observasi yang digunakan dalam penelitian ini dikembangkan sendiri oleh peneliti. Metode observasi yang dikembangkan yaitu berupa lembar observasi. Uji hipotesis yang dilakukan dalam penelitian ini menggunakan analisis uji-t. Data penelitian harus memenuhi uji prasyarat analisis yakni dengan melakukan uji normalitas sebaran data dan uji homogenitas varians.

\section{Hasil dan Pembahasan}

Hasil analisis deskripsi data pre-test, post-test kelompok eksperimen dan kelompok kontrol dapat dilihat pada tabel 1 dan 2 berikut:

Tabel 1. Analisis Deskripsi Data pre-test

\begin{tabular}{lcc}
\hline Keterangan & Eksperimen & Kontrol \\
\hline Nilai tertinggi & 27 & 28 \\
Nilai terendah & 16 & 17 \\
Nilai rata-rata & 21,70 & 21,67 \\
\hline
\end{tabular}

Tabel 2. Analisis Deskripsi Data post-test

\begin{tabular}{lcc}
\hline \multicolumn{1}{c}{ Keterangan } & Eksperimen & Kontrol \\
\hline Nilai tertinggi & 43 & 39 \\
Nilai terendah & 33 & 26 \\
Nilai rata-rata & 39,50 & 31,37 \\
\hline
\end{tabular}

Tabel 4. Hasil Uji Normalitas Sebaran Data Posttest

\begin{tabular}{lcc}
\hline \multicolumn{1}{c}{ Keterangan } & Sig. & A \\
\hline Eksperimen & 0,200 & 0,05 \\
Kontrol & 0,200 & 0,05 \\
\hline
\end{tabular}

Berdasarkan tabel diatas, terlihat bahwa data posttest hasil belajar kelompok eksperimen maupun kelompok kontrol memiliki nilai sig $>0,05$, maka dapat disimpulkan kelompok data tersebut berdistribusi normal.

Tabel 5. Hasil Uji Homogenitas Varians Pretest Kelompok Eksperimen dan Kontrol

\begin{tabular}{ccc}
\hline Sig. & A & Keterangan \\
\hline 0,198 & 0,05 & Homogen \\
\hline
\end{tabular}

Berdasarkan tabel perhitungan diatas didapat nilai Sig. 0,198 $>$ a 0,05 maka data pre-test kedua kelompok memiliki variansi yang homogen. 
Tabel 6. Hasil Uji Homogenitas Varians Posttest Kelompok Eksperimen dan Kontrol

\begin{tabular}{ccc}
\hline Sig. & A & Keterangan \\
\hline 0,832 & 0,05 & Homogen \\
\hline
\end{tabular}

Berdasarkan tabel perhitungan diatas didapat nilai Sig. 0,832 $>\alpha$ 0,05 maka data post-test kedua kelompok memiliki variansi yang homogen.

Pengujian terhadap hipotesis penelitian menggunakan analisis uji-t. Rekapitulasi hasil uji-t terlihat pada tabel 7.

Tabel 7. Hasil Uji-T Pretest-Posttest Kelompok Eksperimen dan Kontrol

\begin{tabular}{cccc}
\hline Statistik & $\mathbf{T}$ & Sig.(2-tailed) & Keterangan \\
\hline Pretest & 0,047 & 0,962 & Setara \\
Posttest & 11,27 & 0,000 & Signifikan \\
\hline
\end{tabular}

Tabel perhitungan diatas pada pretest didapatkan nilai uji-t sebesar 0,047, nilai tersebut lebih kecil dari Sig. (2-tailed) 0,962 maka kelompok eksperimen dan kelompok kontrol sebelum diberikan treatment dapat dikatakan setara. Tabel perhitungan diatas pada posttest didapatkan nilai uji-t sebesar 11,27, nilai tersebut lebih besar dari Sig.(2-tailed) 0,000. Dengan demikian H0 ditolak dan $\mathrm{H} 1$ diterima, hal ini menunjukkan bahwa terdapat pengaruh antara kelompok anak yang memperoleh pengajaran dengan model pembelajaran CTL (Contextual Teaching and Learning) dengan kelompok anak yang tidak memperoleh pengajaran dengan model pembelajaran CTL (Contextual Teaching and Learning) terhadap kemampuan sains permulaan anak pada kelompok B taman kanak-kanak gugus $\mathrm{V}$ Kecamatan Klungkung.

Perbedaan kemampuan sains permulaan kelompok eksperimen dengan kelompok kontrol terjadi karena kegiatan pembelajaran yang menarik dan berbeda dengan menggunakan model pembelajaran contextual teaching and learning (CTL). Model pembelajaran contextual teaching and learning (CTL) sangat tepat digunakan dalam pembelajaran sains karena selama ini pembelajaran sains hanya berpatokan pada buku ajar saja, sehingga kurang menarik bagi anak, dengan model pembelajaran contextual teaching and learning (CTL) ini, maka pembelajaran sains permulaan akan menjadi lebih menarik dan lebih bermakna bagi anak karena dapat menghadirkan situasi nyata kedalam kelas secara konkret.

Sesuai dengan Suastra (2013:113) menjelaskan Model pembelajaran kontekstual merupakan suatu konsepsi pembelajaran yang membantu guru mengaitkan materi (content) yang diajarkan dengan situasi dunia nyata (context) dan mendorong siswa membuat hubungan antara pengetahuan yang dimilikinya dengan penerapannya dalam kehidupan mereka seharihari sebagai anggota keluarga, warga Negara, dan tenaga kerja. Melalui model pembelajaran contextual teaching and learning (CTL) anak diberikan kesempatan untuk mengalami langsung yang dapat membantu anak mengembangkan kemampuan sains permulaan.

Hasil penelitian menunjukkan bahwa kemampuan sains permulaan pada kelompok anak yang diberikan model pembelajaran contextual teaching and learning $(\mathrm{CTL})$ lebih baik dari kelompok anak yang tidak diberikan perlakuan model pembelajaran contextual teaching and learning $(\mathrm{CTL})$, dan tidak terlepas dari pemberian iklim belajar yang memadai, prasarana pembelajaran yang mendukung anak melakukan proses pembelajaran. Kegiatan yang diberikan dalam proses pembelajarannya adalah mengajak anak berekplorasi dan melakukan eksperimen sederhana yang dapat menstimulasi kemampuan sains permulaan. Anak diajak untuk mengamati lingkungan sekitar, bereksplorasi dengan seluruh indra anak, dan melakukan percobaan atau eksperimen-eksperimen sederhana. Melalui model pembelajaran contextual teaching and learning (CTL) anak diberikan kesempatan langsung untuk menyelidiki, 
mengamati, memecahkan masalah dan anak diberikan kesempatan untuk bertanya dan menjelasakan apa yang telah dilakukan dalam mengembangkan kemampuan sains.

\section{Simpulan dan Saran}

Berdasarkan hasil observasi yang dilakukan pada kelompok $\mathrm{B}$ di gugus $\mathrm{V}$ dapat disimpulkan kemampuan sains permulaan masih belum berkembang secara optimal. Selain itu anak-anak tidak diberi kesempatan yang banyak untuk berekplorasi. Model pembelajaran yang digunakan guru belum bisa memaksimalkan dan meningkatkan kemampuan sains permulaan pada anak, sehingga diperlukan model pembelajaran untuk meningkatkan kemampuan sains permulaan anak agar sesuai dan tepat dengan kebutuhan dan perkembangan anak. Selain itu model yang digunakan diharapkan agar anak tidak pasif dan ikut dilibatkan secara langsung, sehingga anak merasa senang dalam mengikuti kegiatan pembelajaran sains.

Hasil yang terjadi dilapangan sungguh berbeda dengan harapan dan standar pendidikan anak usia dini. Adanya kenyataan di lapangan yang belum sesuai dengan kebutuhan anak dalam memberikan stimulasi kemampuan sains permulaan, maka beberapa solusi penggunaan model pembelajaran lain dapat digunakan, stimulasi dalam pembelajaran dapat dilakukan dengan beberapa model-model pembelajaran yang akan memudahkan guru dalam mengajar. Terdapat banyak sekali model pembelajaran yang dapat digunakan di TK, sementara model yang paling cocok digunakan untuk merangsang kemampuan sains permulaan pada anak adalah model pembelajaran CTL (Contextual Teaching and Learning).

Model pembelajaran Contextual Teaching and Learning atau model pembelajaraan kontekstual merupakan model pembelajaran yang menekankan proses keterlibatan anak dalam menemukan sendiri materi pelajaran, mengaitkan materi dengan situasi dunia nyata, sehingga materi tersebut tertanam dalam pemahaman anak, dan materi yang didapat melalui mebelajaran kontekstual dapat diterapkan dalam kehidupan. Pembelajaran kontekstual merupakan usaha untuk membuat anak-anak aktif dalam mengikuti pembelajaran dan meningkatkan kemampuan dirinya. Sebab anak mempelajari konsep sekaligus menerapkan dan mengaitkannya dengan kehidupan nyata. Guru hanya sebagai motivator dan fasilitator dalam kegiatan pembelajaran.

Hasil analisis deskriptif memperoleh nilai rata-rata pada pre-test kelompok eksperimen sebesar 21,70 dan 31,37 post-test pada kelompok eksperimen, pre-test kelompok kontrol sebesar 21,67 dan 31,37 pada post-test kelompok kontrol. Uji normalitas sebaran data untuk skor kemampuan sains permulaan menggunakan bantuan spss 17.00 di Post-test kelompok eksperimen 0,200>0,05, Post-test kelompok kontrol 0,200>0,05 yang berarti data berdistribusi normal. Uji homogenitas data memperoleh hasil 0,198. maka data pre-test kedua kelompok memiliki variansi yang homogen karena nilai uji lebih besar dari taraf signifikansi $5 \%$. Selanjutnya untuk posstest didapat nilai uji homogenitas sebesar 0,832 . maka data post-test kedua kelompok memiliki variansi yang homogen karena nilai uji lebih besar dari taraf signifikansi $5 \%$. Uji hipotesis menggunakan uji-t yang memperoleh hasil 11,27 , nilai tersebut lebih besar dari Sig.(2-tailed) 0,000.

Berdasarkan hasil analisis data, maka simpulan penelitian ini menyatakan bahwa, terdapat pengaruh model pembelajaran contextual teaching and learning (CTL) terhadap kemampuan sains permulaan. Jadi model pembelajaran contextual teaching and learning (CTL) berpengaruh terhadap kemampuan sains permulaan anak kelompok $\mathrm{B}$ di gugus $\mathrm{V}$ Kecamatan Klungkung Tahun Pelajaran 2018/2019.

Berdasarkan hasil penelitian ini, maka saran yang dapat diberikan adalah dalam sebuah pembelajaran seorang pendidik atau guru hendaknya lebih memperhatikan karakteristik peserta didiknya terutama untuk pendidikan anak usia dini. Pendidikan anak usia dini merupakan pendidikan yang diberikan sebelum anak memasuki sekolah dasar untuk mengembangkan seluruh aspek yang dimiliki anak, dimana anak masih belajar secara konkret dan masih membutuhkan fasilitator yang mendukung dalam kegiatan belajarnya.

Pemberian kegiatan dalam pendidikan anak usia dini haruslah didukung dengan sebuah model pembelajaran yang sesuai dengan karakteristik anak. Penerapan pembelajaran CTL 
dalam pendidikan di Taman Kanak-kanak menjadikan pembelajaran lebih bermakna. Anak dapat menangkap hubungan antara pengalaman belajar di sekolah dengan kehidupan belajar. Pembelajaran juga lebih produktif dan mampu menumbuhkan penguatan konsep kepada anak karena anak dituntun untuk menemukan pengetahuan, mengalami secara nyata bukan menghafal. Apabila nantinya akan dilakukan penelitian yang hampir sama, maka hendaknya meneliti bagaimana penggunaan model pembelajaran contextual teaching and learning (CTL) dalam aspek perkembangan anak yang lain.

\section{Daftar Pustaka}

Agung, A. A. G. 2014. Buku Ajar Metodologi Penelitian Pendidikan. Malang:Media Publishing.

Anisah. 2009. "Kelebihan dan Kekurangan Pembelajaran CTL". Tersedia Pada http://kelebihan_dan_kekurangan_pembelajaran_ctl.html.pdf. Diunduh 9 Maret 2019.

Antara, Putu Aditya. 2017. "Menelisisk Fenomena Kelas Kreatif Pada Taman Kanak-Kanak Di Bali". e-journal Universitas Pendidikan Ganesha ISBN: 978-602-6428-11-0. Tahun 2017. Singaraja: Undiksha.

Elizza, Delfi. 2013. "Penerapan Model Pembelajaran Contextual Teaching and Learning (CTL) Berbasis Sentra di Taman Kanak-kanak". Tersedia Pada http://ejournal.unp.ac.id/index.php/pedagogi/article/viewfile/4286/3354. Diakses 9 Maret 2019.

Nugraha, Ali. 2005. Pengembangan Pembelajaran Sains Pada Anak Usia Dini. Jakarta: Departemen Pendidikan Nasional.

Peraturan Menteri Pendidikan dan Kebudayaan Republik Indonesia Nomor 137 Tahun 2014 tentang Standar Pendidikan Anak Usia Dini. 2015. Jakarta: Kementerian Pendidikan dan Kebudayaan RI.

Peraturan Menteri Pendidikan dan Kebudayaan Republik Indonesia Nomor 146 Tahun 2014 tentang Kurikulum Pendidikan Anak Usia Dini. 2015. Jakarta: Kementerian Pendidikan dan Kebudayaan RI.

Rusman. 2012. Model-model Pembelajaran. Jakarta:PT Raja Grafindo Persada.

Sari, A.A. Diah Kartika. "Pengaruh Model Problem Based Learning Terhadap Kemampuan Sains Permulaan Anak". e-journal PGPAUD Universitas Pendidikan Ganesha Volume 6 No1 Tahun 2018. Singaraja: Undiksha.

Suastra, I Wayan. 2013. Pembelajaran Sains Terkini. Singaraja: Universitas Pendidikan Ganesha.

Sugiyono. 2017a. Metode Penelitian Kuantitatif, Kualitiatif dan $R \& D$. 2017. Bandung: Alfabeta.

Sujiono, Yuliani Nurani. 2009. Konsep Dasar Pendidikan Anak Usia Dini. Jakarta: PT Indeks.

Susanto, Ahmad. 2011. Perkembangan Anak Usia Dini. Jakarta: Kencana.

Suyadi. 2010. Psikologi Belajar PAUD (Pendidikan Anak Usia Dini). Yogyakarta: PT Bintang Pustaka Abadi.

Susanto, Ahmad. 2011. Perkembangan Anak Usia Dini. Jakarta: Kencana.

Susanto, Ahmad. 2016. Teori Belajar \& Pembelajaran. Jakarta: Prenada Media Group. 
Trianto. 2009. Mendesain Model Pembelajaran Inovatif Progresif. Jakarta: Kencana Prenada Group.

Undang-undang Nomor 20 Tahun 2003 Pasal 28 tentang Sistem Pendidikan Nasional. Jakarta: Kementerian Pendidikan dan Kebudayaan RI. 